This item was submitted to Loughborough's Research Repository by the author.

Items in Figshare are protected by copyright, with all rights reserved, unless otherwise indicated.

\title{
Feminist digital art history
}

PLEASE CITE THE PUBLISHED VERSION

http://www.routledge.com/9781138585584

\section{PUBLISHER}

Routledge

VERSION

AM (Accepted Manuscript)

PUBLISHER STATEMENT

This is an Accepted Manuscript of a book chapter published by Routledge in Introduction The Routledge Companion to Digital Humanities and Art History on 04 May 2020, available online:

http://www.routledge.com/9781138585584

\section{LICENCE}

CC BY-NC-ND 4.0

\section{REPOSITORY RECORD}

Brown, Kathryn, and Elspeth Mitchell. 2020. "Feminist Digital Art History”. figshare. https://hdl.handle.net/2134/11974302.v1. 


\section{FEMINIST DIGITAL ART HISTORY}

\section{Kathryn Brown and Elspeth Mitchell}

One of the questions posed in the present volume is whether the use of digital technologies in the field of art history can generate new models for the analysis and interpretation of art, its sociocultural contexts, and institutional frameworks? If that question is answered in the affirmative, what new knowledge is generated, and how do computational methods impact on the discipline of art history itself? These questions seem particularly pertinent to feminist engagements with artworks, museology, and histories of creative production. If feminism has sought to understand and typically to challenge - the role played by gender in structuring narratives of art history, do methodologies proposed by the digital humanities assist or hamper the realization of that ambition? More specifically, is it possible to identify a branch of "digital art history" as specifically "feminist" and, if so, what might this mean? The aim of this chapter is to debate these issues in light of recent research and exhibition projects and to examine the possibilities and limitations of what might be termed "feminist digital art history."

Before proceeding, it is worth bearing in mind that bringing together the terms "digital," "feminism," and "art history" is itself a task that is fraught with prior assumptions. Each of these terms has links to diverse histories, methods, socio-political contexts, and cultural frameworks that demand scrutiny. As Amelia Jones has noted in her approach to the study of feminism and visual culture, when analyzing the intersection of such fields, it is necessary to remain alert to their respective "modes of thinking, making, doing or strategizing" in order to understand how they may inflect each other. ${ }^{1}$ Equally, the notion of a "feminist digital art history" is one that demands 
a high level of terminological self-reflection on the part of the researcher - including as to different possible meanings depending on what the term "feminist" means and where it appears in the formulation. In the following discussion, we will use "feminist" as a modifier of "digital art history" and will consider the various implications of so doing in the final section of the chapter.

\section{Virtual Encounters}

In her 2007 book Encounters in the Virtual Feminist Museum, Griselda Pollock proposes a feminist mode of reading "against the grain" of art history's classificatory systems by means of a central concept: the virtual feminist museum. ${ }^{2}$ In developing this idea, Pollock stresses that such a museum is not virtual in the sense of an online platform. Rather, it is a space of encounter that allows individuals to trace new "critical relations" among artworks and, ultimately, between each other. ${ }^{3}$ This would be, Pollock argues, a forward-looking, experimental museum that brings together artworks assembled by a feminist (as opposed to phallocentric) logic. At the time of writing the book, Pollock considered such a museum to be unrealizable under then current capitalist and patriarchal conditions:

It signals a museum that could never be actual. The dominant social and economic power relations that govern the museum make feminist analysis impossible. What corporation would sponsor a feminist intervention which challenges the assumptions of class, race and gender that underpin the current social system despite gestures of inclusiveness and minor corrections to its histories of discrimination? ${ }^{4}$

"Feminism," according to Pollock, is a critical interrogation of patriarchal culture that imagines different forms of sociality and culture. Described as a "research laboratory" and "exhibition" in book form, the virtual feminist museum aims to counter the tendency towards mastery, 
classification, and definition that Pollock argues has been favored by both the modernist museum and dominant discourses of art history.

As a "poïesis of the future," Pollock's project seeks to stage encounters in which to think through, and intervene in, art's histories by staging "transformative interactions between the images differently assembled in conversations framed by feminist analysis and theory." ${ }^{5}$ Pollock critically works through images in differential encounters that rupture established conventions and networks. Thus, the virtuality of her feminist museum is inscribed philosophically rather than technologically. Drawing on Elizabeth Grosz's notion of "becoming feminist" as a work of constant analysis and conceptual innovation, the virtual feminist museum must remain, for Pollock, a potentiality. ${ }^{6}$

Why introduce "feminist digital art history" through a concept that Pollock seeks specifically to distance from the online platforms and digital tools that have become the familiar frameworks and methodologies of digital art history? Our reasons are twofold: first, "feminism" is understood in Pollock's analysis as a political stance. Her desire to imagine encounters in the virtual feminist museum addresses some of the key issues at stake in exploring connections between "feminism" and "art history," and it is necessary to unpack those debates in order to understand what "feminist digital art history" is or might be. Secondly, Pollock employs vocabulary and concepts that have become pillars of the digital humanities: networks and mapping. Her discussion does, therefore, anticipate some of the methodologies that inform digital art history and its desire to unearth hitherto under-appreciated or unseen patterns and associations. Indeed, Pollock's discussion of Aby Warburg's Mnemosyne Atlas and Pathosformel are models that have been taken up and developed through a variety of digital techniques and to different ends as discussed in chapters 27 and 28 of the present volume. The question that arises is whether the 
political ambitions of feminist art history are met by the digital tools that appear to give its proposals visible form. Put differently, what happens when a "poïesis of the future" is realized in a technological present?

We might initially compare feminist art history and digital art history in the following way. Pollock presents a feminist reconceptualization of ways in which audiences experience and study the visual arts by proposing new concepts with which to examine and intervene in art's histories. Digital art history, as a field that uses computational and analytical methods enabled by new technology, also aims to reconceptualize the way in which we experience and study the visual arts and thus also challenges traditional discourses that have shaped the discipline. ${ }^{7}$

"Feminism" and "digital" are thus two qualifiers that modify the study and writing of "art history." Feminism, on the one hand, is a politics and theory that problematizes gender, sex, sexual difference, and sexuality in ways that can be used to inform art practice and scholarship. Digital art history, on the other hand, is a method and set of tools. According to Susan Gagliardi and Joanna Gardner-Huggett, art historians tend to conflate theory and method:

When art historians characterize their approaches as feminist, iconographic, Marxist, or something else, they explain how their evidence coincides with or challenges certain concepts or interventions rather than clarify how they obtained their evidence or analyzed it. This foregrounding of theory over method results in presentations and publications that eschew the iterative nature of research. ${ }^{8}$

Theory only offers a way of organizing or transforming information and is often undertaken with an end point in mind (for example making visible the ideological basis of the erasure of certain artists). In consequence, Gagliardi and Gardner-Huggett stress the need to account for the "how" of art-historical research, an approach that entails exploring more fully the interaction between 
different methodological models and underlying data. ${ }^{9}$ How, then, can feminism challenge the ways in which digital art history formulates its key questions or wrestles with issues such as the limits of data?

\section{Overview of Principal Strategies}

In order to begin to answer these questions, it is necessary to locate our discussion in an overview of some recent art-historical projects and approaches that are located at the intersection of the digital humanities and feminism. In the following discussion, the "field" of feminist digital art history is taken broadly to mean computational methods, analytical technologies, and digitization strategies that are related to the lives and careers of female artists, artworks by women, or that otherwise problematize interactions between gender and the canons of art history, including the methodologies used to study the latter.

\section{Re-Mapping the Terrain}

Mapping is a mainstay of digital art history. As discussed in Chapter 7, research groups such as Artl@s promote and develop new tools to support this method of investigation. Artl@s specifically positions its mapping work as an attempt to disturb art history's grounding in nationalistic narratives and monographic studies. ${ }^{10}$ It argues that digital mapping is a key method for adding to knowledge about art, but also for transforming the way such knowledge is employed in dominant art-historical narratives. If Pollock encouraged researchers to read "against the grain" of art history, the mapping strategies promoted by Art1@s have a similar transformative ambition.

Joanna Gardner-Huggett and Michelle Moravec have each used mapping as a tool for arthistorical research on feminist artists. ${ }^{11}$ Writing in 2017, Gardner-Huggett argues, following Lucy 
Lippard's writing on feminist art practices, that the digital mapping of artistic networks is part of an important genealogy of art-historical research into feminist art networks. ${ }^{12}$ Her research traces histories of women's collaborative practice (in this case two Chicago-based collectives: ARC Gallery and Artemisia Gallery) and uses digital techniques, such as Geographic Information Systems (GIS), to visualize networks according to location. ${ }^{13}$ The digital methods produced results that offered a corrective to her previous research findings, suggesting earlier research had overvalued national engagement in an attempt to insert the collectives into existing narratives of feminist art.

Michelle Moravec has led two digital humanities projects that use social network analysis for research on feminist artists. In both, Moravec was concerned with testing the use and limits of social network analysis for feminist artists who had been marginalized within dominant discourses. Describing the research in 2017, she outlines how Visualizing Schneemann sought to explore American artist Carolee Schneemann's artistic relationship with other women through analysis of correspondence collected in the edited volume Correspondence Course, edited by Kristine Stiles. ${ }^{14}$ The second project examined the manifesto in feminist art as a means of circulating ideas. ${ }^{15}$ Moravec describes how both projects failed to produce the results for which she had hoped. The results demonstrated that network analysis has limited use if artworks and archival materials relating to female artists remain under-processed in comparison to that of their male counterparts:

Even in the case of Schneemann, among a handful of the most celebrated female artists of her generation, network analysis proved quite difficult. Her archived letters are less 
processed than her male peers, making it impossible to create a thorough correspondence network of her extant letters. ${ }^{16}$

Digital art history research on artists who are women has been constrained by a scarcity of archives, insufficient amounts of machine-readable materials, and limited (or biased) metadata attached to images and artifacts. ${ }^{17}$ This situation is a symptom of broader systemic and structural issues that have failed adequately to account for the contributions of artists who are women and/or people of color, working class, disabled, trans, or queer. It is precisely these ideological and cultural structures that have been addressed by feminist, queer, and decolonial critiques of art history. The digitization of artworks and texts by feminist artists, women, and marginalized or oppressed individuals - and the forging of an adequate vocabulary for the meta-data attaching to such works - is an important part of building a feminist digital art history.

In the projects discussed above, mapping is used to make visible the histories of feminist artists and art collectives for the purpose of examining interactions between individuals and groups. Moravec, in particular, is concerned with testing the use and limits of social network analysis for research on feminist artists who have been marginalized in dominant discourses. Another approach is to examine how a feminist perspective might shape GIS digital methods in art-historical research. Gardner-Huggett's research is informed by the ideas of feminist geographer Mei-Po Kwan. ${ }^{18}$ Kwan examines the limitations of GIS methods and considers how they may be reoriented in the light of feminist epistemologies and politics. By "deconstructing the dualist understanding of geographical methods (as either quantitative or qualitative)" and by enacting a "feminist visualization" that undermines the objectifying gaze of the "master subject," Kwan argues for a new kind of critical engagement between researcher and subject matter. ${ }^{19}$ Taking up this point, Gardner-Huggett points out that digital mapping does not, in and of itself, offer a 
radically different form of feminist research within its art-historical application. Rather than simply replace analogue with digital methods, she argues that digital mapping complements the former and "makes the art historian more accountable to historical sources." 20

\section{Online Encounters}

Online platforms and exhibitions are a significant form of digital art history and have become important sites of feminist activity. Broadly, these take the following forms: online indices of female artists and feminist exhibitions; exhibitions of work by women realized solely on online platforms; websites that are constructed to accompany feminist exhibitions; and social media platforms created for the presentation and discussion of art by women.

Three examples of the first category include AWARE (Archives of Women Artists, Research and Exhibitions), Art + Feminism, and N.paradoxa. Co-founded in 2014 by Camille Morineau, AWARE is a website that seeks to restore "the presence of $20^{\text {th }}$-century women artists in the history of art." ${ }^{21}$ It does so by compiling an online, searchable index that profiles the biographies of female artists born between 1860 and 1972 regardless of their country of origin or the media in which they worked. The index draws from the Dictionnaire universel des créatrices, an online encyclopedia developed by Éditions des femmes and Antoinette Fouque, a key figure in the French Women's Liberation Movement. ${ }^{22}$ The index is continually updated and is accompanied by paper and online publications, research events, and reviews of exhibitions by female artists.

AWARE is a collaborative project that solicits contributions from the public for its content. In this regard it is similar to Art + Feminism that describes itself as "a campaign improving coverage of gender, feminism, and the arts on Wikipedia." ${ }^{23}$ By organizing edit-a-thons, Art + 
Feminism organizes events (both virtual and physical) that mobilize members of the public to collaborate in the production and dissemination of knowledge about the relationship between gender and art.

The website N.paradoxa, run from the UK by feminist art historian Katy Deepwell, is an online repository of links to research on feminism and contemporary art. The website, launched in 1996, catalogues feminist research on post-1970 art and aims "to promote understanding of women artists and their work" through a database of over 5000 links. ${ }^{24}$ The material represented concern feminism's relation to contemporary art and range from archives and exhibitions to books and theses. ${ }^{25}$ While each of these projects seeks to redress imbalances in publicly available information, they also use technology to encourage discussion and to foster collaborative practices designed to have a broader impact on the artworld.

Inevitably, social media play an important role in realizing the activist potential of online audiences. Social media accounts that specifically engage with artworks made by women or that question the canon of art history have emerged and grown in popularity over the past five years. While the Guerilla Girls have long been noted for their feminist interventions at museums, art fairs, and other events, their web page is now an important source of information and archive of projects, and their Instagram account (@guerillagirls), launched in 2012, showcases their various activities and posters. ${ }^{26}$ Similar social media accounts that raise awareness about the relationship between gender and the artworld include \#WOMENSART (@womensart1), launched in January 2016 by PL Henderson, which shares artwork by women in different media; and on Instagram, @thegreatwomenartists, an account run by Katy Hessel since October 2015, which describes its aim as "celebrating female art daily." At the time of writing \#WOMENSART has amassed over 
220,000 followers on Twitter, @guerillagirls 70,000 followers on Instagram, and @ thegreatwomenartists 66,500 followers.

Presence and visibility online is essential for artists and institutions. Consequently, dedicated websites that accompany museum exhibitions have been a key output in the realization of major feminist survey exhibitions. These "blockbuster" feminist shows, as Hilary Robinson has noted, had a surge of popularity in major Western museums between 2005 and 2011. ${ }^{27}$ Reesa Greenberg, writing in 2015, draws attention to the social and historical significance of dedicated websites for such exhibitions:

Most exhibition websites are not produced as history but become history. After exhibitions are over, the websites remain online as "permanent," accessible alternatives to existing print format exhibition histories. Moreover, because of the expanded possibilities of what can be recorded and presented online, exhibition websites offer viable models for documenting and analyzing exhibitions differently. ${ }^{28}$

Constructing dedicated websites for temporary feminist exhibitions organized by museums is an important tool, she argues, for challenging the patriarchal structures of the artworld. ${ }^{29}$ Greenberg concludes that by leaving a trace of the exhibition online, such websites can counter the erasure of women from printed histories.

Roszika Parker and Griselda Pollock have argued that the erasure of women from histories of art is symptomatic of ideological assumptions about sexual difference that have structured the development of the discipline. ${ }^{30}$ Greenberg diagnoses a similar issue in the more recent field of exhibition histories, but suggests that the medium of the website can produce content that resists 
the categorizations and hierarchies of earlier discourses and practices. A website's multimedia capabilities is especially well suited to the types of feminist artwork pioneered in the 1970s such as performance and video art.

Greenberg's optimism is countered, however, by the lifespan and legacies of online projects. Maura Reilly, for instance, has reflected on her ambitions as the founding curator of the Elizabeth A. Sackler Center for Feminist Art (part of the Brooklyn Museum, USA) for a website to accompany the inaugural exhibition of the center, Global Feminisms: New Directions in Contemporary Art, in 2007:

The web is the greatest educational tool, so, from the outset, I set the goal of developing an extensive, interactive website, housed within the Brooklyn Museum site. [...] I also designed the Feminist Art Base, the first online digital archive dedicated solely to feminist art. It was meant to be an ever-growing database that offered multimedia profiles from the most prolific contributors to feminist art from the 1960s to the present. [...] the goal was to make this ground breaking searchable archive a comprehensive resource for artists, curators, scholars, and the general public. It was meant to be continually expanding. When it was launched in 2007 there were 550 profiles. Today, there are only 320, and the profiles no longer feature videos or performance clips, only $2 \mathrm{D}$ works. ${ }^{31}$

Although Reilly's aims align with Greenberg's conceptualization of the positive function of the website as an "accessible alternative" to print, the project was not sustained with the energy with which it was initiated. Reilly also notes that important features of the online database, including the inclusion of video clips, are now defunct. Within a decade, the website not only failed to 
expand, but actually diminished. If Greenberg is right, should such projects be sustained and, if so, how are they to be adequately supported both technologically and financially? Part of a feminist digital art history is the need to create, maintain and search for visual and archival material. Three key practical issues that arise in this context are: first, the effective tagging of existing material (i.e. metadata that adequately reflects and contextualizes the gendered biographies of artifacts and exhibitions); secondly, the digitization of a broad range of resources as discussed above; and thirdly, the creation and implementation of strategies to maintain born-digital materials (including the preservation of relevant software and hardware).

\section{Exhibitions, Gender, and Cyberfeminism}

Beginning in March 2019, the Richard Saltoun Gallery, a commercial gallery in London, dedicated a year of programming to female artists. Titled " $100 \%$ Women," the programme included gallery exhibitions, art fair presentations, talks, external collaborations, and digital exhibitions on a new online platform hosted on the gallery's website. ${ }^{32}$ As press materials highlighted, several of the online exhibitions featured unrepresented and emerging artists, thus serving as "part of its [the gallery's] commitment to nurturing greater inclusivity." ${ }^{33}$ That the launch of the online exhibition platform coincided with the $100 \%$ Women initiative, not only acknowledges gender-based inequalities in the art market, but optimistically suggests that online exhibitions may be one strategy for addressing the issue. ${ }^{34}$

The Saltoun Gallery is not alone in its use of the internet to exhibit and promote the work

of women artists and, indeed, most artists now have their own sophisticated online presences. ${ }^{35}$ Yet, the key issue in this case is not simply one of visibility. Rather it concerns how technology relates to institutional frameworks that have been shaped by gendered power relations. This is a 
topic with which artists, activists, and "cyberfeminists" have long grappled. While it would go beyond the scope of this chapter to discuss the long and complex history of the relationship between art, technology, and gender, it is worth positioning the present discussion against the background of a few key examples that have a bearing on institutional power structures in the artworld. The first is the Art and Technology project run between 1967 and 1971 by the Los Angeles County Museum of Art that was intended to demonstrate emerging connections between art, engineering, science, and other technologies. No women were included in the initiative. ${ }^{36} \mathrm{In}$ her discussion of the project and the formation of the Los Angeles Council of Women Artists (LACWA) in its wake, Jennifer Way discusses LACWA's criticism of the museum and of the ways in which a combination of technology and gender reinforced prevailing patriarchal power structures: technology was gendered as masculine, women were cast as cultural consumers rather than producers, and these ideas were understood as normative elements of social (and museum) organization. ${ }^{37}$

Judy Wajcman's studies of the gendering of technology provide important overviews of the development of women's relationship to science and computing from the 1970s to the present. She notes that while feminists of the 1980s remained largely "pessimistic about the prospects for women offered by the microelectronic revolution, there was a much more enthusiastic response to the dawn of the digital age." ${ }^{38}$ Fuelled by ideas that cyberspace had the possibility to overturn notions of biological difference, the figure of the cyborg (as proposed by Donna Haraway) and the liberating prospects of virtual realities seemed to offer new possibilities for the subversion of traditional notions of gender, embodied experience, and power relations. ${ }^{39}$ Yet, as Wajcman notes: 
A common argument $[\ldots]$ is that the digital revolution heralds the decline of traditional institutional practices and power bases including patriarchal power. The virtuality of cyberspace is seen to spell the end of naturalized, biological embodiment as the basis for gender difference. ${ }^{40}$

The limitations of the impact of the digital revolution on the practices of art institutions was brought to the fore, however, by Cornelia Sollfrank in 1997 in a work titled Female Extension. The artist famously hacked a competition of net art run by the Hamburg Kunsthalle. ${ }^{41}$ By creating fake submissions by 127 female artists, she sought to test and disrupt ideologies that underpinned the museum's processes of selection and reward. Although the institution approvingly noted the high submission rate by women, none of them won a prize in the competition. As Merle Radtke puts it: "By occupying the net art competition. Sollfrank questioned long-established institutional structures and practices at various levels, and revealed invisible but thoroughly influential power relations." 42

Various collectives and research groups have arisen over the past decade that interrogate contemporary technologies from a feminist perspective and create communities that share resources about relationships between technology, pedagogy, arts, and culture. FemTechNet describes itself as a "cyberfeminist praxis: we recognize that digital and other technologies can both subvert and reinscribe oppressive relations of power and we work to make these complex relations of power transparent." ${ }^{43}$ It seeks to do so through a range of initiatives including research projects, social media postings, online courses, and publications. Groups with similar aims and a focus on encouraging diversity in technology and research include Deep Lab, MzTek, Mz Baltazar's Lab, and the Fembot Collective. ${ }^{44}$ 
Online exhibitions have become part of contemporary, everyday culture and often seek to make visible the work and ideas of artists who are underrepresented in major museum collections. Having regard to the issues discussed above, it is important to consider the relationship between online and physical exhibitions. On the one hand, online exhibitions seem to have the power to alter the ways in which gender has shaped narratives of art history. By bringing to light works that have not been incorporated into museums and by giving voice to under-represented artists, they can enhance artworld diversity. On the other hand, however, web exhibitions risk falling into the realm of digital ephemera as discussed above and, in consequence, may reinforce existing canons by failing to provide a lasting platform for individuals who have been excluded from those canons. Having regard to the ideas underpinning Pollock's virtual feminist museum, an online exhibition is not a simple corrective to an historic lack of visibility. Rather, the strategic importance of such initiatives lies in their ambition to provoke change that extends beyond virtual reality and that impacts on institutional practices and wider social behavior (including the greater presence of women and minorities in both the arts and technology).

Unsurprisingly, feminist online projects range from the individual (e.g. Les Femmes Folles: Women in Art) to the institutional. ${ }^{45}$ As an example of the latter, Google Arts \& Culture (formally Google Art Project) has been used as a platform for developing media projects, online exhibitions and photo stories (often in collaboration with arts and culture organizations and collections) to present work that examines relationships between gender, culture, and society. ${ }^{46}$ Clearly, a key aim of these media projects is to give wider access to works of art and material culture from the contributing partners. In 2011, Nancy Proctor discussed the significance of these kinds of initiatives in terms of access and experience: 
High-resolution images and high-definition video are a good example of how the Web and digital media can be used to complement, rather than imitate, the encounter with the artwork in the gallery. Nelson Mattos, vice-president of engineering at Google, celebrates the access that the Internet provides for those who cannot physically travel to distant museums. The Google Art Project promises to enrich that online art experience both informationally and emotionally. ${ }^{47}$

The significance is not just more visibility for artworks, but the promotion of a unique form of engagement and access: high-resolution images and high-definition video allow the close scrutiny of objects alongside a different way of searching the collection catalogue and encountering curated online exhibitions. Proctor captures the excitement of this new kind of art experience: "Watch the technophobes zoom into a gigapixel painting for the first time, and see the scales fall from their eyes when they realize they can't get this close to the art even in the gallery." ${ }^{4}$

Although Google offers such engagement through its Arts \& Culture interface there remains a risk of creating a skewed image of art history through uneven access to collections due to high reproduction fees, partnership obligations, and copyright obstacles. Other practical difficulties arise: what about artworks that resist digitization because of their material composition? What criteria will organizers use to decide what is worth reproducing? Extending Wajcman's skepticism about the utopian promise of the digital revolution, limits attaching to the creation of online platforms may simply reinstate the patriarchal logic that has, to date, informed art-historical canons. This risks once again dismissing artwork made by women or other marginalized groups in the structure of newly created digital collections and exhibitions. ${ }^{49}$ One might also add that there is a need to look beyond the interface to the structure of the corporation 
that funds and maintains the relevant site. Just as museums are coming under pressure to be more transparent and accountable as regards their governance and funding, it is reasonable to consider the corporate culture of Google itself - including the sexism scandals in which was embroiled in 2018 - when considering the extent to which the Google Arts and Culture platform is, in fact, a tool for advancing gender equality. ${ }^{50}$

\section{Potential and Limitations}

Many of the examples discussed above optimistically suggest that digitization, the strategic use of computer technologies, and shared approaches to learning and online activities can offer the possibility of disrupting conventional art-historical narratives by foregrounding issues of gender and diversity. Echoing the positive rhetoric that surrounded the advent of the internet and of computer art in the 1990s, digital humanities methodologies have seemed to promise a similar democratization of research culture: greater access to materials through digitization; the creation of search and mapping tools to unearth hidden histories; increased collaboration and publication of open access resources; and the creation of platforms that showcase the creativity of individuals who have been omitted from traditional artworld institutions.

Critics of the digital humanities have, however, pointed out the limitations of many approaches that have developed in the field to date. In 2014, Martha Nell Smith debated the consequences of studying "frozen social orders when they are made to seem like objective features of intellectual life." ${ }^{51}$ While her discussion focused on the challenges of working in digital archives, she also opened wider questions about humanities research, namely how to "transform

the digital humanities so that innovations are sociological and not only technical." ${ }^{52}$ Developing this point, Roopika Risam has argued for an intersectional digital humanities - one that "asks us 
to begin with the specificities of a data set, identify the layers of difference that intersect within it, and use that knowledge as a basis for project design." ${ }^{53}$ In a similar vein, scholars including Kim Gallon and Angel Nieves have called for increased interaction between Africana/Black Studies and the digital humanities. In Gallon's view a "black epistemology will generate questions about the relationship between the racialization of humanity and the digital as power, ultimately fostering new inquiries and deeper understandings about the human condition." 54

While the authors cited above query the composition of datasets and the kinds of questions posed about them, issues relating to who undertakes (or is able to undertake) a project in the digital humanities are also important in this context. Attention has been drawn to gender and identity formation when examining the diversity of scholars in the digital humanities. Moya Z. Baily notes that the "ways in which identities inform both theory and practice in digital humanities have been largely overlooked. Those already marginalized in society and the academy can also find themselves in the liminal spaces of this field." ${ }^{55}$ One could add to this the need to confront even more basic issues of inequality. As digital humanities projects are reliant on adequate infrastructure (including access to sophisticated computing equipment, software, and technology training), only a limited range of institutions around the world are able to support such research.

The questions raised by these branches of scholarship are relevant to debates about what might constitute feminist digital art history and how it is practised. This involves debating the role that technology plays in determining both the kinds of questions posed by digital projects and the ways in which the latter relate to the goals of humanities research and to notions of academic community. In this vein, Janneke Adema and Gary Hall have called for a style of digital humanities that is essentially "disruptive" in nature. They identify two major threats to the functioning and development of the digital humanities. They argue that the discipline remains within the 
boundaries of the traditional humanities and is, therefore, simply a transposition of its key tenets and ideas into a digital realm. Furthermore, they worry that research relies too heavily on the approaches and methodologies of computing science and business technologies. ${ }^{56}$ Their suggestion is a more radical overhaul of approaches to humanities research as a general matter, including critical re-assessments of the methodologies, aesthetics, and dissemination of research and of the institutions in which that research takes place. Adema and Hall's call to arms aligns with conceptions of feminist scholarship that view the remit of the field as extending beyond issues of methodology and to encompass practices of protest culture. Viewed from this angle, one aspect of feminist digital art history may consist in developing research strategies that do not simply mobilize new scholarly approaches to intersections of art history and technology, but that do so with the ambition of provoking wider social change. ${ }^{57}$

The issues raised in this context are also relevant to more general debates about the gendering of technologies and algorithms that underpin digital humanities research. In Artificial Knowing, Alison Adam examines "the ways in which gender, in the form of concepts of masculinity and femininity, is inscribed, in implicit ways" in artificial intelligence ("AI"). ${ }^{58}$ Key to her examination of the relationships between gender and $\mathrm{AI}$ is an increased focus on the subject of the knowledge - the "knower." Locating her analysis against the background of feminist epistemology and, in particular, the work of Lorraine Code, Adam highlights the need to maintain focus on the cultural contexts and status of knowers themselves and to be wary of AI that privileges a traditional epistemological model based on "knowing that" as opposed to "knowing how." ${ }^{59}$ Her discussion is relevant to the subject of this chapter as it encourages researchers to reflect critically on the algorithms used to undertake digital humanities projects and to test the assumptions on which they are built. 
Adam's focus on epistemological self-reflection in computing also suggests an overlap with feminism and the ways in which it relates to the field of art history. As Griselda Pollock has noted, terms such as "race," "gender," "sexuality," and "class" are not "descriptions of given conditions of human beings or inert categories. They are dynamic social signs. They signify materially lived sets of differential and asymmetrical and intersecting relations. [...] They are terms in the making of cultural meanings, and thus in the making of the subjects of such meaning: subjectivity." ${ }^{60}$ Taking up the debate about terminology with which we opened this chapter, reflection on the cultural complexity of category distinctions that structure both feminism and digital humanities is crucial to determining both the field of feminist digital art history and the role of the researcher within it.

In his discussion of the role of the imagination in the age of computing, Ed Finn makes a comment that is important to the relationship between technology, the humanities, and the lens through which we comprehend the world:

Ambiguity, dissonance, interpretation, affect: these are the playing fields of humanistic and artistic inquiry. The subject position of the reader becomes increasingly important when the algorithmic portal through which we are accessing the universe of knowledge is itself an active agent, shaping the framing and the tenor of our gaze. ${ }^{61}$

Finn's comment aligns with concerns enunciated by Adam and, as discussed above, by Kwan, but emphasizes a term that is central to art history: the gaze. An interrogation of the gaze - whether as a perspective embedded in an artwork or the view of an actual spectator - has been central to twentieth- and twenty-first-century art history and has motivated powerful and enduring debates 
about gendered looking. If, in some measure, digital art history is a delegation of the gaze to an algorithm - a new lens through which one looks at an artwork - feminist digital art history calls for renewed attention to the implications of this act. Rather than understanding feminist digital art history as simply a range of methodologies or exhibition projects pertaining to gender that use computer technologies as new means of analysis and visualization, this field of study calls for a more fundamental inquiry into how such technologies are reshaping the gaze of the researcher/viewer. This not only includes consideration of the gendered premises that are built into search engines or that shape databases and online collections. Rather, it also requires attention to the socio-cultural contexts of knowing more generally. If this debate has been undertaken primarily in media and literary studies and in science and technology, art historians have much to offer by bringing their own conceptions and critiques of the gaze to the fore. It is not simply the case that digital technologies can reshape art history, but rather that art history has the analytical tools to question key concepts that have driven the emergence of those technologies and the implications they have for structuring relationships of power between observer and subject.

\section{Notes}

${ }^{1}$ Amelia Jones, 'Introduction': in Amelia Jones (ed.), The Feminism and Visual Culture Reader, $2^{\text {nd }}$ edition (London and New York: Routledge, 2010), 1-2.

${ }^{2}$ Griselda Pollock, Encounters in the Virtual Feminist Museum: Time, Space and the Archive (Abingdon: Routledge, 2007). 
${ }^{3}$ Ibid., 13.

${ }^{4}$ Ibid., 9-10.

${ }^{5}$ Ibid., $10-11$.

${ }^{6}$ Elizabeth Grosz, Time Travels: Feminism, Nature, Power (Durham and London: Duke University Press, 2005).

${ }^{7}$ The Artl@s project, for example, explicitly positions itself as redefining art history "by embracing the theories and methods of the spatial, global, and digital turns that have challenged humanities over the past decades." Béatrice Joyeux-Prunel, Catherine Dossin, and Sorin Adam Matei, "Spatial (Digital) History: A Total Art History?-The ARTL@S Project,"Visual Resources, 29, no. 1-2 (2013): 47-58.

${ }^{8}$ Susan Gagliardi and Joanna Gardner-Huggett, "Spatial Art History in the Digital Realm," Historical Geography, 45, no.1 (2017), 23.

${ }^{9}$ Ibid.

${ }^{10}$ Béatrice Joyeux-Prunel, Catherine Dossin \& Sorin Adam Matei, "Spatial (Digital) History: A Total Art History?_The Artl@s Project,"Visual Resources, 29, no.1-2, (2013), 48.

${ }^{11}$ Joanna Gardner-Huggett, "Extrapolating Influence: The Challenge of Mapping the History of ARC and Artemisia Galleries, Chicago (1980-1985),” Historical Geography, 45, no.1 (2017); Michelle Moravec, "Network Analysis and Feminist Artists," Artl@s Bulletin 6, no. 3 (2017).

${ }^{12}$ Gardner-Huggett, "Extrapolating Influence.”

${ }^{13}$ Ibid., 46.

${ }^{14}$ Kristin Stiles, Correspondence Course (Durham and London: Duke University Press, 2010).

${ }^{15}$ Moravec examined digitized US women's liberation movement periodicals to discover which feminist art manifestos had been reprinted, cross referencing the periodicals with the anthology 
Feminist Art Manifestos edited by Katy Deepwell (2014). See: Katy Deepwell, Feminist Art Manifestos: An Anthology (London: KT Press, 2014).

${ }^{16}$ Moravec, "Network Analysis and Feminist Artists," 80.

17 Ibid.

18 Mei-Po Kwan, "Feminist Visualization: Re-envisioning GIS as a Method in Feminist Geographic Research," Annals of the Association of American Geographers, December 2002, 645-61.

${ }^{19}$ Kwan, "Feminist Visualization,” 656.

${ }^{20}$ Gardner-Huggett, “Extrapolating Influence,” 58.

${ }^{21}$ https://awarewomenartists.com/en/a propos/ (Accessed on 27 August, 2019).

22 https://www.dictionnaire-creatrices.com/en/ (Accessed on 3 September, 2019).

${ }^{23}$ http://www.artandfeminism.org/ (Accessed on 27 August, 2019).

${ }^{24}$ https://www.ktpress.co.uk/ (Accessed on 5 September 2019).

${ }^{25}$ https://www.ktpress.co.uk/feminist-art-observatory.asp (Accessed on 5 September 2019).

${ }^{26}$ https://www.guerrillagirls.com/our-story (Accessed on 27 August, 2019).

${ }^{27}$ Hilary Robinson, "Feminism Meets the Big Exhibition: Museum Survey Shows since 2005," OnCurating, 29, (May 2016): 29-41.

28 The exhibitions discussed are: WACK! Art and the Feminist Revolution; Global Feminisms; elles@centrepompidou. Reesa Greenberg, "Museums, Women, and the Web," in The International Handbooks of Museum Studies: Museum Transformations, ed. Annie E. Coombes and Ruth B. Phillips (Hoboken: John Wiley \& Sons, 2015), 472.

${ }^{29}$ Greenberg, "Museums, Women, and the Web", 471. 
${ }^{30}$ Roszika Park and Griselda Pollock, Old Mistresses: Women, Art and Ideology (London and New York: I.B. Tauris, 2013), 49.

${ }^{31}$ Maura Reilly, "Foreword" in Feminism and Museums: Intervention, Disruption and Change, ed. Jenna C Ashton (Edinburgh: MuseumsEtc, 2017).

${ }^{32}$ https://www.richardsaltoun.com/online-exhibition/ (Accessed 5 September, 2019).

${ }^{33}$ https://www.richardsaltoun.com/exhibitions/70/overview/ (Accessed 5 September, 2019).

${ }^{34}$ See research conducted by Freelands Foundation: Marijke Steedman, "Representation of Female Artists in Britain in 2017," https://freelandsfoundation.co.uk/research/representation-of-femaleartists-in-britain-2017, accessed 5 September, 2019.

35 Other examples include The National Association of Women Artists Inc (https://www.nawaonlinegallery.org/home); Fusion.art (https://fusionartps.com/); Art Gallery Online (https://www.contemporaryartgalleryonline.gallery/2019-art-competition-all-women); LightSpaceTime (https://www.lightspacetime.art/all-women-art-exhibition-january-2018/).

${ }^{36}$ See Maurice Tuchman and Jane Livingston, A Report on the Art and Technology Program of the Los Angeles County Museum of Art 1967-1971 (Los Angeles: Los Angeles County Museum of Art, 1971). In his Introduction, Tuchman notes that a high proportion of female artists submitted unsolicited proposal for the project, but that none of these were accepted (19).

${ }^{37}$ Jennifer Way, "Digital Art and the Interface of Technology and Feminism," in: A Companion to Digital Art, ed. Christiane Paul (Malden MA and Oxford: Wiley Blackwell, 2016), 181-202 $(185-6)$.

38 Judy Wajcman, "Feminist Theories of Technology," Cambridge Journal of Economics, 34 (2010), 141-52 (147). 
${ }^{39}$ Donna Haraway, “A Cyborg Manifesto: Science, Technology, and Socialist-Feminist in the Late Twentieth Century" in Donna Haraway, Simians, Cyborgs and Women: The Reinvention of Nature (New York: Routledge, 1991), 149-81.

${ }^{40}$ Judy Wajcman, TechnoFeminism (Cambridge: Polity Press, 2004), 7.

${ }^{41}$ For a discussion of this and similar Cyberfeminist works see Charlotte Frost, Art Criticism Online: A History (Canterbury: Gylphi, 2019), 97-8.

${ }^{42}$ Merle Radtke, "Female Extension: A Cyberfeminist Intervention" in Feminism and Museums: Intervention, Disruption and Change, vol. 1, edited by Jenna C. Ashton (Edinburgh: Museums Etc, 2018), 537-47 (545).

${ }^{43}$ https://femtechnet.org/publications/manifesto/ (Accessed 30 August, 2019). August, 2019)

${ }^{45}$ Les Femmes Folles: Women in Art: https://femmesfollesnebraska.tumblr.com/about (Accessed 30 August, 2019).

${ }^{46}$ Examples include, Road to Equality, a platform exploring stories to celebrate one hundred years of women's rights in the UK through a curated assemblage of visual and textual material. Others are Women in Culture, exploring the impact of women in culture across arts, humanities and sciences, and Faces of Frida, a project that looks at Frida Kahlo's life, art and legacy.

${ }^{47}$ Nancy Proctor, "The Google Art Project: A New Generation of Museums on the Web?," Curator: The Museum Journal, 54, no.2 (2011): 215-16.

${ }^{48}$ Ibid., 218. 
${ }^{49}$ Ibid., 216.

${ }^{50}$ For reports on this issue see Daisuke Wakabayashi and Katie Benner, "'How Google Protected Any Rubin, the 'Father of Android'," The New York Times, October 25, 2018 (https://www.nytimes.com/2018/10/25/technology/google-sexual-harassment-andy-rubin.html) and Amy Nelson, "Google and the Structural Sexism of the American Workplace,” Forbes, 30 October, 2018 (https://www.forbes.com/sites/amynelson1/2018/10/30/google-and-the-structuralsexism-of-the-american-workplace/\#411b73052d70). Accessed 30 August, 2019.

${ }^{51}$ Martha Nell Smith, "Frozen Social Relations and Time for a Thaw: Visibility, Exclusions, and Considerations for Postcolonial Digital Archives," in: Journal of Victorian Culture, 19:3, 403-10 (404).

${ }^{52}$ Ibid.

${ }^{53}$ Roopika Risam, "Beyond the Margins: Intersectionality and the Digital Humanities.” DHQ: $\begin{array}{llllll}\text { Digital Humanities } & \text { Quarterly, } & \text { vol. } & 9, & \text { no. } & 2\end{array}$ http://www.digitalhumanities.org/dhq/vol/9/2/000208/000208.html. See also Elizabeth Losh, Jacqueline Wernimont, Laura Wexler, and Hong-An Wu, "Putting the Human Back into the Digital Humanities: Feminism, Generosity, and Mess," in: Debates in the Digital Humanities, Ch. 10, (Minneapolis, MN.: University of Minnsesota Press, 2016). https://dhdebates.gc.cuny.edu/read/65be1a40-6473-4d9e-ba75-6380e5a72138/section/cfe1b125$\underline{6917-4095-9 \mathrm{~d} 56-20487 \mathrm{aa} 0 \mathrm{~b} 867 \# \mathrm{ch} 10}$

${ }^{54}$ Kim Gallon, "Making a Case for the Black Digital Humanities" in Matthew K. Gold and Lauren F. Klein (eds), Debates in the Digital Humanities 2016 (Minneapolis: University of Minnesota Press, 2016. $\quad$ https://dhdebates.gc.cuny.edu/read/65be1a40-6473-4d9e-ba756380e5a72138/section/fa10e2e1-0c3d-4519-a958-d823aac989eb\#ch04 
${ }^{55}$ Moya Z. Baily, "All the Digital Humanists Are White, All the Nerds Are Men, But Some of Us are Brave" in Journal of Digital Humanities, vol. 1. no. 1 (2011). http://journalofdigitalhumanities.org/1-1/all-the-digital-humanists-are-white-all-the-nerds-aremen-but-some-of-us-are-brave-by-moya-z-bailey/

${ }^{56}$ Janneka Adema and Gary Hall, "Posthumanities: The Dark Side of 'The Dark Side of the Digital'," Journal of Electronic Publishing, vol. 19, issue 2, Fall 2016, DOI: http://dx.doi.org/10.3998/3336451.0019.201.

${ }^{57}$ See Hilary Robinson, "Introduction," A Companion to Feminist Art, edited by Hilary Robinson and Maria Elena Buszek (Hoboken, NJ: Wiley Blackwell, 2919), 6. See also Hester Baer, 'Redoing Feminism: Digital Activism, Body Politics, and Neoliberalism," in: Feminist Media Studies, vol. 16 , no. $1,17-34$.

${ }^{58}$ Alison Adam, Artificial Knowing: Gender and the Thinking Machine (London and New York: Routledge, 1998), 1.

${ }^{59}$ Ibid., 30.

${ }^{60}$ Griselda Pollock, "Essentialism, Feminism, and Art: Spaces Where Woman 'Oozes Away”, in A Companion to Feminist Art, ed. Robinson and Buszek, 261-282 (270).

${ }^{61}$ Ed Finn, What Algorithms Want: Imagination in the Age of Computing (Cambridge Mass: The MIT Press, 2017), 195-6.

\section{Bibliography}

Adam, Alison. Artificial Knowing: Gender and the Thinking Machine (London and New York: Routledge, 1998). 
Adema, Janneka and Gary Hall, "Posthumanities: The Dark Side of 'The Dark Side of the Digital'," Journal of Electronic Publishing, vol. 19, issue 2, Fall 2016, DOI: http://dx.doi.org/10.3998/3336451.0019.201

Art+Feminism. Accessed 27 August, 2019. http://www.artandfeminism.org/.

AWARE: Archives of Women Artists, Research \& Exhibitions. “Our programmes.” Accessed 27 August, 2019. https://awarewomenartists.com/en/a propos/.

Bailey, Moya Z. "All the Digital Humanists Are White, All the Nerds Are Men, But Some of Us are Brave" in Journal of Digital Humanities, vol. 1. no. 1 (2011). http://journalofdigitalhumanities.org/1-1/all-the-digital-humanists-are-white-all-the-nerds-aremen-but-some-of-us-are-brave-by-moya-z-bailey/.

Contemporary Art Gallery Online. "2019 All Women Art Exhibition and Competition Prospectus." Accessed 15 October 2019. https://www.contemporaryartgalleryonline.gallery/2019art-competition-all-women.

Deep Lab. Accessed 30 August, 2019. http://www.deeplab.net/\#home.

Deepwell, Katy. Feminist Art Manifestos: An Anthology (London: KT Press, 2014).

Charlotte Frost, Art Criticism Online: A History (Canterbury: Gylphi, 2019).

Gardner-Huggett, Joanna. "Extrapolating Influence: The Challenge of Mapping the History of ARC and Artemisia Galleries, Chicago (1980-1985)," Historical Geography, 45, no.1 (2017): 3765.

Fembot Collective. Accessed 30 August, 2019. https://fembot.adanewmedia.org/.

FemTechNet. "Manifesto." $\quad$ Accessed $30 \quad$ August 2019. https://femtechnet.org/publications/manifesto/. 
Finn, Ed. What Algorithms Want: Imagination in the Age of Computing (Cambridge Mass: The MIT Press, 2017).

Fusion.art. Accessed 15 October 2019. https://fusionartps.com/.

Gagliardi, Susan and Joanna Gardner-Huggett, "Spatial Art History in the Digital Realm," Historical Geography, 45, no.1 (2017): 17-36.

Gallon, Kim. "Making a Case for the Black Digital Humanities" in Matthew K. Gold and Lauren

F. Klein (eds), Debates in the Digital Humanities 2016 (Minneapolis: University of Minnesota Press, $2016 . \quad$ https://dhdebates.gc.cuny.edu/read/65be1a40-6473-4d9e-ba756380e5a72138/section/fa10e2e1-0c3d-4519-a958-d823aac989eb\#ch04.

Greenberg, Reesa. "Museums, Women, and the Web," in The International Handbooks of Museum Studies: Museum Transformations, ed. Annie E. Coombes and Ruth B. Phillips (Hoboken: John Wiley \& Sons, 2015), 471-488.

Google Arts and Culture. "Faces of Frida." Accessed 15 October 2019. https://artsandculture.google.com/project/frida-kahlo

Google Arts and Culture. "Road to Equality." Accessed 15 October 2019. https://artsandculture.google.com/project/road-to-equality

Google Arts and Culture. "Women in Culture." Accessed 15 October 2019. https://artsandculture.google.com/project/women-in-culture.

Grosz, Elizabeth. Time Travels: Feminism, Nature, Power (Durham and London: Duke University Press, 2005).

Guerilla Girls. "Our Story.” Accessed 27 August, 2019. https://www.guerrillagirls.com/our-story. 
Donna Haraway, "A Cyborg Manifesto: Science, Technology, and Socialist-Feminist in the Late Twentieth Century" in Donna Haraway, Simians, Cyborgs and Women: The Reinvention of Nature (New York: Routledge, 1991), 149-81.

Jones, Amelia (ed.). The Feminism and Visual Culture Reader, $2^{\text {nd }}$ edition (London and New York: Routledge, 2010).

Joyeux-Prunel, Béatrice, Catherine Dossin, and Sorin Adam Matei, "Spatial (Digital) History: A Total Art History?_The ARTL@S Project,"Visual Resources, 29, no. 1-2 (2013): 47-58.

KT press/ n.paradoxa. "Feminist Art Observatory." Accessed 27 August, 2019. https://www.ktpress.co.uk/feminist-art-observatory.asp.

Kwan, Mei-Po. "Feminist Visualization: Re-envisioning GIS as a Method in Feminist Geographic Research," Annals of the Association of American Geographers, December 2002, 645-61.

Le Dictionnaire universel des Créatrices._Accessed 27 August, 2019. https://www.dictionnairecreatrices.com/en/.

Les Femmes Folles. "About." Accessed 30 August, 2019. https://femmesfollesnebraska.tumblr.com/about.

LightSpaceTime. “All Women” Art Exhibition - January 2018.” Accessed 15 November 2019. https://www.lightspacetime.art/all-women-art-exhibition-january-2018/.

Losh, Elizabeth, Jacqueline Wernimont, Laura Wexler, and Hong-An Wu, "Putting the Human Back into the Digital Humanities: Feminism, Generosity, and Mess," in: Debates in the Digital Humanities, Ch. 10, (Minneapolis, MN.: University of Minnsesota Press, 2016). https://dhdebates.gc.cuny.edu/read/65be1a40-6473-4d9e-ba75-6380e5a72138/section/cfe1b1256917-4095-9d56-20487aa0b867\#ch10

Moravec, Michelle. "Network Analysis and Feminist Artists," Artl@s Bulletin 6, no. 3 (2017). 


\begin{tabular}{lllllll}
\hline $\mathrm{Mz}$ & Baltazar's & Lab. & "About."
\end{tabular}

http://www.mzbaltazarslaboratory.org/about/.

MzTEK. “A Community of Technologists.” Accessed 30 August, 2019. https://mztek.org/.

National Association of Women Artists, Inc. "NAWA Online Exhibitions.” Accessed 15 October 2019. https://www.nawaonlinegallery.org/home.

Nelson, Amy. "Google and the Structural Sexism of the American Workplace," Forbes, 30

October, 2018.

Parker, Roszika and Griselda Pollock, Old Mistresses: Women, Art and Ideology, (London and New York: I.B. Tauris, 2013).

Pollock, Griselda. Encounters in the Virtual Feminist Museum: Time, Space and the Archive (Abingdon: Routledge, 2007).

Pollock, Griselda. "Essentialism, Feminism, and Art: Spaces Where Woman 'Oozes Away'”, in $A$ Companion to Feminist Art, ed. Robinson and Buszek, 261-282.

Proctor, Nancy. "The Google Art Project: A New Generation of Museums on the Web?," Curator:

The Museum Journal, 54, no.2 (2011): 215-221. doi:10.1111/j.2151-6952.2011.00083.

Radtke, Merle. "Female Extension: A Cyberfeminist Intervention" in Feminism and Museums:

Intervention, Disruption and Change, vol. 1, edited by Jenna C. Ashton (Edinburgh: Museums Etc, 2018), 537-47.

Reilly, Maura. "Foreword" in Feminism and Museums: Intervention, Disruption and Change, ed. Jenna C Ashton (Edinburgh: MuseumsEtc, 2017), 16-41.

Richard Saltoun Gallery. "Online Exhibition.” Accessed 5 September, 2019. https://www.richardsaltoun.com/online-exhibition/. 
Risam, Roopika. "Beyond the Margins: Intersectionality and the Digital Humanities." $D H Q$ : Digital Humanities Quarterly, vol. 9, no. 2 (2019): http://www.digitalhumanities.org/dhq/vol/9/2/000208/000208.html.

Robinson, Hilary. "Feminism Meets the Big Exhibition: Museum Survey Shows since 2005," OnCurating, 29, (May 2016): 29-41.

Robinson, Hilary and Maria Elena Buszek, eds. A Companion to Feminist Art (Hoboken, NJ: Wiley Blackwell, 2919).

Smith, Marsha Nell. "Frozen Social Relations and Time for a Thaw: Visibility, Exclusions, and Considerations for Postcolonial Digital Archives," in: Journal of Victorian Culture, 19:3, 403-10 Stiles, Kristin. Correspondence Course (Durham and London: Duke University Press, 2010).

Tuchman, Maurice and Jane Livingston, A Report on the Art and Technology Program of the Los Angeles County Museum of Art 1967-1971 (Los Angeles: Los Angeles County Museum of Art, 1971)

Wajcman, Judy. "Feminist Theories of Technology," Cambridge Journal of Economics, 34 (2010), $141-52$.

Wakabayashi, Daisuke and Katie Benner, “'How Google Protected Any Rubin, the 'Father of Android'," The New York Times, October 25, 2018.

Way, Jennifer. "Digital Art and the Interface of Technology and Feminism," in: A Companion to Digital Art, ed. Christiane Paul (Malden MA and Oxford: Wiley Blackwell, 2016), 181-202.

Wilson, Judith. "One Way or Another: Black Feminist Visual Theory" in Jones (ed.), The Feminism and Visual Culture Reader, 19-23. 